\title{
SPATIAL PLANNING DETERMINANTS OF COHESION POLICY IMPLEMENTATION IN POLISH REGIONS
}

\author{
Tomasz Komornicki (D) , Barbara Szejgiec-Kolenda (D) , Bożena Degórska (1) , Katarzyna Goch, Przemysław \\ Śleszyński (iD , Maria Bednarek-Szczepańska (D) , Piotr Siłka \\ Institute of Geography and Spatial Organization, Polish Academy of Sciences \\ Twarda 51/55, 00-818 Warsaw: Poland \\ t.komorn@twarda.pan.pl, b.szejgiec@twarda.pan.pl, bodego@twarda.pan.pl, gochkatarzyna@gmail.com, \\ psleszyn@twarda.pan.pl, bednarek@twarda.pan.pl, piotrsilka@wp.pl
}

\begin{abstract}
The main objective of the paper is to present directions of mutual interrelationships between the state of spatial planning (at different levels of public administration) and effective cohesion policy, conceived as operational programmes carried out in Poland in the years 2004-2016. In the research study, the following results were attained: defining the basic planning conditions of development policies implementation resulting from integration with $\mathrm{EU}$, indicating the consequences of these conditions for territorial governance and for the implementation of cohesion policy, as well as identifying the solutions adopted by Poland lying at the intersection between spatial development and investments financed by the EU funds. The paper presents the most important challenges, adopted solutions and effects of their utilization in Poland within three thematic issues: a) polycentricity and suburbanisation, b) transport infrastructure and accessibility and c) natural and cultural heritage.
\end{abstract}

Keywords: territorial governance, spatial planning, cohesion policy, Territorial Agenda 2020.

\section{Introduction}

Polish planning system becomes often the subject of criticism for not meeting the requirements of rapidly developing economy and for being unable to sufficiently prevent the negative processes, such as uncontrolled suburbanisation and spatial chaos (Kowalewski et al. 2018). Despite such strong stimuli as accession to the European Union (EU) and cohesion policy funds, spatial planning system in Poland was not able to instantly adapt to socio-economic transformation. Problems have arisen at all levels - national (large-scale planning inertia), regional (disorganized planning hierarchy) and local (land use policy pathology). The scale of these difficulties has been significantly differentiated in both sectoral and regional terms. These occur with varying strength in spatial units of diverse socio-economic functions and are particularly identified in dynamic metropolitan areas (suburbanisation zones), in newly developed transport corridors, but also in peripheral and border areas as well as the ones with important environmental functions. Polarization in economic development, strong migration processes as well as historically and culturally based differences have resulted in diverse spatial development issues to be faced 
by regions of Poland. Intensification of infrastructure investments due to the influx of EU funds has resulted in new challenges for the planning system (ESPON COMPASS Final Report 2018).

At the same time, in Poland, scale and effects of EU support are deemed as highly positive - since Poland has been so far the greatest beneficiary of structural assistance (considering the size and low GDP of nearly all of its regions). Considerable part of the aforesaid assistance was distributed in a decentralized way (by way of 16 operational programmes). In the subsequent programming periods, these funds were fully and mostly rationally utilized. However, this success required sometimes special legal solutions (special acts enacted in the field of spatial planning, the so-called special purpose law), since the normal planning procedure made it impossible to effectively carry out large-scale investments.

In view of the above-mentioned reasons, Poland seems to be an adequate research field for evaluating the effects of planning circumstances on the EU cohesion policy. The research study was conducted under ESPON COMPASS project in the 2016-2018 period. Apart from the overview of planning systems and territorial governance, the project's objective was to investigate mutual interrelationships and cross-fertilization between these systems and EU policies (more broadly: see Cotella 2018 in the issue).

The goal of the paper is to show mutual interrelationships between the state of spatial planning (at different levels of public administration) and effectiveness of cohesion policy, understood in the sense of operational programmes carried out in the years 2004-2016. The paper deals with the problem concerning the process of spatial planning system adaptation, practice of territorial governance as well as the principles of development policy largely based on EU structural funds under the conditions existing in Poland. Moreover, the authors have undertaken an evaluation of changes going on in planning and programming of developmental policies in Poland, as well as of their effects on land-use planning and spatial order. In the further part, the paper presents research methods and system of spatial planning, as well as provide description of scale and structure of the EU cohesion policy in Poland. Against this backdrop, three thematic issues are discussed: polycentricity and suburbanisation, transport infrastructure and accessibility, natural and cultural heritage. Finally, conclusions and recommendations in the context of potential changes in the Polish planning system are presented, with reference to the cohesion policy principles in the future programming period (after 2020).

\section{Materials and methods}

The study carried under the ESPON COMPASS project concentrated primarily on the analysis of the relationship between cohesion policy and spatial planning systems/territorial governance in practice, on the one hand taking account the system of spatial planning as a foundation for an efficient and effective absorption of resources, and on the other - effect of cohesion policy on the shaping of the principles behind spatial planning system (more broadly: see ESPON COMPASS Final Report - Additional Volume 2 Methodology 2018).

In line with the project guidelines it has been assumed that the evaluation of the mutual interrelationships between spatial planning or territorial governance and EU policies should take place under the framework of the purposely defined thematic issues, indirectly corresponding to some of the priorities defined in the EU Territorial Agenda 2020 (2011). It has been assumed that in case of Poland the following topics are of particular importance: a) promoting polycentric and balanced territorial development (priority 1 TA EU 2020), b) improving territorial connectivity for individuals, 
communities and enterprises (priority 5) and c) managing and connecting ecological, landscape and cultural values of regions (priority 6).

Altogether, the research study was conducted in 16 regions belonging to 6 European countries (France, Hungary, Ireland, Poland, Spain and Sweden) representing both various spatial planning models, as well as differentiated level of importance attached to instruments of cohesion policy (cf. Hans \& Böhme 2018; Pámer 2018; Perger 2018; Smas \& Lidmo 2018; Williams \& Varghese 2018). As regards Poland, the case studies involved 3 NUTS 2 regions: łódzkie (thematic issue: transport infrastructure and accessibility), podlaskie (thematic issue: natural and cultural heritage) and mazowieckie voivodeships (thematic issues: polycentricity, suburbanisation together with transport infrastructure and accessibility). The selection of thematic issues was associated with specific developmental circumstances of given regions (Table 1).

In order to identify mutual interactions between development policy and spatial development the following measures were conducted: (1) desk research based on a review of policy documents, projects or programmes implementation and evaluation reports at the national and regional level, connecting cohesion policy and other sectoral policies with spatial planning, (2) semi-structured interviews ( 6 interviews with representatives of scientific community specialising in problems of spatial planning and programming of development policy and (3) focus group workshops (3 workshops with 47 participants from 3 case study regions discussing current dilemmas of regional and local dimension of territorial governance). Interviews and workshops took place in September and October 2017.

Table 1. Characteristics of case study regions

\begin{tabular}{|l|l|}
\hline Voivodeship (NUTS 2) & \multicolumn{1}{c|}{ Description } \\
\hline Łódzkie & $\begin{array}{l}\text { tódzkie is characterised by a moderate level of economic development and internal } \\
\text { diversification of economic development that continues to grow. The economic potential } \\
\text { of the voivodeship lies in its high level of industrialisation (the highest share of industry } \\
\text { in GVA generation anywhere in Poland). tódzkie is relatively well-served by its road } \\
\text { network, and a further great advantage lies in a location on the crossroads of two core } \\
\text { TEN-T corridors. A major shortcoming of the existing road layout is its bad technical } \\
\text { condition. }\end{array}$ \\
\hline Mazowieckie & $\begin{array}{l}\text { Mazowieckie is the most diversified region in Poland in terms of socio-economic } \\
\text { development. It has well-formed services, industrial and agriculture sectors, } \\
\text { and the metropolis of Warsaw as a pole of growth. The settlement system is unbalanced } \\
\text { in terms of demographic potential and supply-demand labour market, resulting in strong } \\
\text { commuting. Divergence increases as a result of the outflow of population to Warsaw } \\
\text { metropolis, though this does not apply to the large and medium-sized cities, endangered } \\
\text { by severe depopulation. }\end{array}$ \\
\hline Podlaskie & $\begin{array}{l}\text { Podlaskie is situated peripherally in the north-eastern part of Poland. This region, } \\
\text { characterised by the lowest population density in Poland. The agro-food industry } \\
\text { is the main branch of its economy, and the region is unique even on a European scale } \\
\text { as regards its natural and cultural assets. Podlaskie has experienced a very high emigration } \\
\text { rate, with rural areas left considerably depopulated, to the point where disruption } \\
\text { of demographic structure and further depopulation might ensue. }\end{array}$ \\
\hline
\end{tabular}

Source: own elaboration based on ESPON COMPASS Final Report - Additional Volume 6 Case Studies (2018). 


\section{Systemic determinants of spatial planning, territorial governance and cohesion policy in Poland}

Poland's accession into the EU had a significant effect on the processes of development management and spatial planning in Poland. As a result, following 2004 (and before 2004 under pre-accession measures) adaptation processes to EU standards were taking place with regard to acquiring and disbursement of funds, entailing systemic changes in territorial governance and spatial planning as well as changes in the logic of development programming towards territorial cohesion (Fig. 1). Undoubtedly, the EU policy was a determinant factor for these processes, due to which a considerable financial resources were allocated to investment projects in Poland, which in reality contributed also to pursuing the objectives of the Community. Among the preparatory measures in the pre-accession period one may also include, to a certain degree, administration reform of 1998. Empowerment of regional authorities was aimed inter alia at preparing them for the role of administrator of the part of structural funds. In this case one can say about top-down processes that influenced the re-orienting directions and priorities of national policy-making in response to Europeanization (cf. Börzel \& Risse 2000; Dühr et al. 2007; Cotella \& Janin Rivolin 2011). However Europeanization is not only one way process, but also, to a certain extent, vice versa - domestic situation in member states (in this case in Poland) inspired EU policy (bottom-up perspective). This concerned in particular regional and national challenges, which were important from the European perspective, and which were successfully solved at the level of member states (Börzel \& Risse 2000).

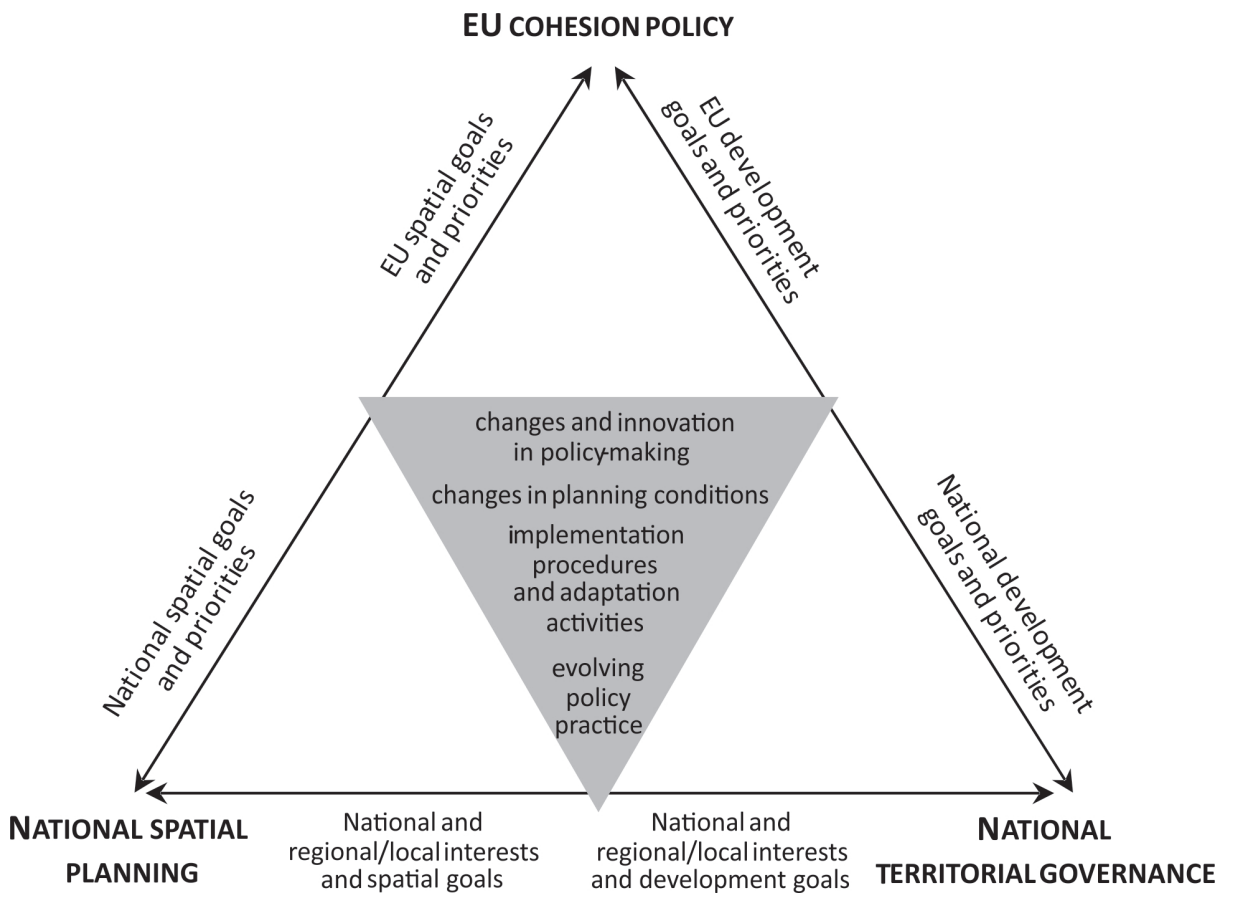

Figure 1. Relations and mutual influences of spatial planning - territorial governance - cohesion policy at the EU, national and regional level

Source: own elaboration based on ESPON COMPASS questionnaire for Poland. 
Apart from mutual relationships between development policies carried out at the EU and member states levels, the system of territorial governance is influenced also by the particular sectoral policies as well as regulations concerning spatial planning. In Poland, law creation and policy-making competencies are concentrated at higher levels of administration (i.e., central or voivodeship), whereas competencies concerning spatial planning are largely shared between all levels of authority, and it is the local government's responsibility to shape proper local spatial development plans. Such situation may bring about conflicts between national and regional priorities. Thus far, these conflicts have concerned infrastructural investments and actions towards environment protection due to high intensity of undertaken activities.

\section{Spatial planning and territorial governance practice}

During the time of socialist economy in Poland, spatial planning was part of ideologically controlled social engineering (Węcławowicz 2002). At a time when the economic transformation began, the very word 'planning' became a negative symbol of the former socio-economic system. Simultaneously, the first local government reform took place. Municipalities (communes) received significant competencies in regard to spatial planning. Meanwhile, local authorities were under enormous pressure from land owners who strived for transformation of land into land for building purposes with intent to sell these sites as soon as possible. Institutional and political changes caused that the property rights over land were identified with the principle of freedom of construction. At the same time, spatial policy at the regional level was hampered by the binding territorial division (49 small voivodeships that actually still constituted delegation of central authorities). National spatial policy was practically non-existent at that time (documents coming from the pre1989 period were in force; Komornicki 2018).

In 1999, second local government reform was carried out simultaneously with administrative territorial division reform of the whole country. The number of voivodeships was reduced from 49 to 16 , instituting at the same time one additional intermediate level in the form of 379 counties (LAU 1). Three-tier territorial division of Poland was introduced with municipality (commune) (LAU 2) and county (LAU 1) as entirely independent local governments, and voivodeship (NUTS 2) as a region having both local government (local parliament), as well as central government aspects (voivod - representative of central government). Counties are lacking competencies in the field of spatial planning. Within voivodeship's competencies is among others preparing two basic strategic documents: a) voivodeship development strategy, and b) voivodeship spatial policy (in time also plans for potential metropolitan areas). The role of voivdeship's local government was strengthened after Poland's accession into the EU, when voivodeships authorities became administrators of a significant part of funds coming from the European Regional Development Fund (through 16 regional operational programmes). The voivodeship authorities have become since that time the evaluators of central and even European-level documents (Komornicki 2018).

The current Spatial Planning and Land Development Act has been in force since 2003. Pursuant to its provisions the entities dealing with spatial planning in Poland are as follows: central government, voivodeship and municipal (local) governments (Gorzym-Wilkowski 2013). Central government prepares the National Spatial Development Concept (the current one was adopted in 2011). The Act invalidated former local spatial development plans (adopted before 1994). Since only few municipalities managed to adopt the new plans after 1995, the invalidation could obstruct planned investments. Therefore legislators decided to facilitate investments in the areas that were not covered by local spatial development plans. This was possible on the basis of "decision on land development or building permission for public purpose investment" (an administrative deci- 
Table 2. Spatial planning and implementation of programmes financed by the EU in case regions

\begin{tabular}{|c|c|c|c|c|c|c|c|c|c|c|c|c|c|c|c|}
\hline \multirow{3}{*}{$\begin{array}{l}\text { Voivodeship } \\
\text { (NUTS 2) }\end{array}$} & \multicolumn{4}{|c|}{$\begin{array}{c}\text { Voivodeship area } \\
\text { covered by local spatial } \\
\text { development plans (\%) }\end{array}$} & \multicolumn{2}{|c|}{$\begin{array}{c}\text { Number of decisions } \\
\text { per } 10 \text { thousand population }\end{array}$} & \multicolumn{4}{|c|}{$\begin{array}{l}\text { Contribution from EU funds (FS, EFRR, EFS) } \\
\text { in projects carried out in the 2007-2013 } \\
\text { perspective (mln euro)* }\end{array}$} & \multicolumn{2}{|c|}{$\begin{array}{l}\text { Plan of EU funds } \\
\text { allocation (FS, EFRR, } \\
\text { EFS) in the 2014-2020 } \\
\text { perspective (mln euro) }\end{array}$} & \multicolumn{3}{|c|}{$\begin{array}{l}\text { Contribution from EU funds (FS, } \\
\text { EFRR, EFS) in projects carried } \\
\text { out in the 2014-2020 perspective } \\
\text { (mln euro) (as of } 31 \text { Dec. 2016)* }\end{array}$} \\
\hline & \multicolumn{2}{|c|}{ in total } & \multicolumn{2}{|c|}{\begin{tabular}{|c|} 
of which \\
on the basis \\
of Act \\
of 2003 \\
in total
\end{tabular}} & \multirow{2}{*}{$\begin{array}{l}\text { building } \\
\text { permission } \\
\text { for public } \\
\text { purpose } \\
\text { investment }\end{array}$} & \multirow[t]{2}{*}{$\begin{array}{l}\text { on land building } \\
\text { conditions } \\
\text { and development }\end{array}$} & \multirow[t]{2}{*}{ total } & \multirow[t]{2}{*}{$\begin{array}{l}\text { total per } \\
\text { capita } \\
\text { (thousand } \\
\text { EUR) }\end{array}$} & \multirow[t]{2}{*}{$\begin{array}{c}\text { national } \\
\text { programmes }\end{array}$} & \multirow[t]{2}{*}{$\begin{array}{c}\text { regional } \\
\text { programmes }\end{array}$} & \multirow[t]{2}{*}{ total } & \multirow[t]{2}{*}{$\begin{array}{c}\text { regional } \\
\text { programmes }\end{array}$} & \multirow[t]{2}{*}{ total } & \multirow[t]{2}{*}{$\begin{array}{c}\text { national } \\
\text { programmes }\end{array}$} & \multirow[t]{2}{*}{$\begin{array}{l}\text { regional } \\
\text { programmes }\end{array}$} \\
\hline & 2010 & 2017 & 2010 & 2017 & & & & & & & & & & & \\
\hline Łódzkie & 29.0 & 32.7 & 35.8 & 44.8 & 6.9 & 44.0 & 4403.9 & 1.8 & 5561.3 & 974.7 & - & 2256.0 & 778.5 & 261.2 & 517.2 \\
\hline Mazowieckie & 28.9 & 32.2 & 42.4 & 54.4 & 6.9 & 33.9 & 4403.9 & 0.8 & 5561.3 & 974.7 & - & 2089.8 & 2522.5 & 2159.9 & 362.7 \\
\hline Podlaskie & 14.3 & 16.8 & 58.9 & 64.2 & 9.9 & 49.0 & 1935.5 & 1.6 & 4578.7 & 623.7 & - & 1213.6 & 500.5 & 315.8 & 184.7 \\
\hline Poland & 26.5 & 30.5 & 50.0 & 61.7 & 7.3 & 37.9 & 65228.2 & 1.7 & 49598.0 & 15630.3 & 76866.5 & 31276.9 & 17376.5 & 11481.9 & 5894.6 \\
\hline
\end{tabular}

* data in Polish złoty converted into euro based on average rate for relevant period as stated by National Bank of Poland

Source: own elaboration based on Statistics Poland (GUS) data. 
sion, later referred to as decision on land development). Coverage by local spatial development plans at the moment of passing the Act amounted to ca. $23 \%$, and currently it is close to $30 \%$ of the Poland's area (it is markedly diversified, e.g., in podlaskie it is on average equal to $17 \%$, cf. Table 2). This is the reason why the investments were carried out on a mass scale on the basis of decision on land development. This followed inter alia from tightened requirements which were imposed by legislators with reference to local spatial development plans. It is thought that exactly this mechanism of decision on land development (in 2017 on average close to 40 decisions on land development per 10 thousand population were issued) contributed to accelerated uncontrolled suburbanisation, as well as to dispersed development in the rural areas and to general deterioration of spatial order. As a consequence, these processes posed the threats to natural environment and brought about high costs of public utility infrastructure. Adoption of the above-mentioned solution caused that land reserves for high-level investments (including those designated for transport investments) were endangered. In this situation, a number of special purpose acts were passed that concerned inter alia road, rail, air, power industry investments, and separately even investments associated with the organization of European Football Championships held in Poland (2012; Komornicki 2018).

\section{Cohesion policy implementation}

An evolution in approach to cohesion policy in Poland may be attributed to the subsequent financial perspectives and broken down into the following periods: (a) pre-accession period 1990-2003, which concentrated on laying foundations for the system of management over EU funds and developing capacities for absorption of funds, with a particular attention to the period immediately before accession (2000-2003); (b) 2004-2006 - the first incomplete EU financial perspective carried out in Poland; (c) 2007-2013 - period characterized by changes in logic of management of EU funds toward decentralization, and (d) 2014-2020 - consistent development of the system worked out in the previous period.

Since the beginning of 1990s economic transformations in Poland were directly supported financially and technically by the EU, primarily by Phare Programme funds. Totally by the end of 1999, Poland obtained in the form of non-refundable subsidies approximately 1.2 bn EUR (yearly ca. $0.2 \%$ of GDP), allocated to the programmes pursuing the regional policy goals, transborder cooperation and activities of structural character, as well as supporting institutional development of administration and potential beneficiaries of structural funds. Directions and the level of pre-accession funding allocated for structural activities after 2000 was defined by Preliminary National Development Plan - contribution coming from EU subsidies amounted to 2.4 bn EUR (yearly ca. $0.4 \%$ GDP). Changes were introduced in the Phare programme priorities which were adjusted in line with the standards associated with EU accession. These changes concerned mainly institutional development, investments oriented towards socio-economic cohesion, and also towards development of infrastructure conditioning the economic activity. In that time also, two new programmes were developed for Poland that were additional instruments supporting preparations for EU membership, i.e., ISPA (investment projects helping to adjust infrastructure associated with natural environment protection and transport) and SAPARD (investments facilitating the quality of production of agricultural farms and local infrastructural investments in the rural areas).

National Development Plan 2004-2006 (NPR) was the document that defined implementation of EU funds in the years 2004-2006. Its strategic goal was development of competitive economy based on knowledge and entrepreneurship, capable for long-term development, ensuring growth in employment and improvement of social, economic and spatial cohesion with EU 
at the regional and national level. NPR constituted the basis indicating directions and the planned contribution of resources stemming from structural funds, cohesion funds and national funding. Total sum of funding awarded to Poland by EU for the purposes of NPR amounted to $12.8 \mathrm{bn}$ EUR. In order to meet the NPR goals, the special implementation instruments were devised which were managed at the national level by the particular government ministries. These instruments were as follows: Integrated Operational Programme for Regional Development (ZPORR), which was granted the largest portion of funding, Sectoral Operational Programme 'Human Resource Development', Sectoral Operational Programme 'Improvement of the Competitiveness of Enterprises', Sectoral Operational Programme 'Transport', Technical Assistance Operational Programme and programmes concerning agricultural policy and Community initiatives (EQUAL, INTERREG III).

It was only when programming and programmes of financial perspective 2007-2013 were developed that the change in logic of the utilization of EU funds took place. The National Strategic Reference Framework was in that period the most important document defining the basic goals of cohesion policy and indicating major directions/priorities of support carried out by means of instruments in Poland. Its strategic objective was to create appropriate conditions for growth of competitiveness of Polish economy based on knowledge and entrepreneurship, securing the growth in employment and increase in the level of social, economic and spatial cohesion. Poland in the years 2007-2013 was the greatest beneficiary of the European cohesion policy, under its framework Poland received in total more than 65 bn EUR (Table 2), therefore the overall scale of investment was markedly higher. On average contribution from the EU funds constituted approximately $3 \%$ of GDP (including national funding and own resources) and in economically poorer voivodeships the level of this funding was much higher than in well-developed voivodeships (3.5\% in podlaskie vs. close to $1 \%$ in mazowieckie). The largest share of funds was allocated to 'Infrastructure and Environment Operational Programme' managed at the central level focusing on investments in energy, supply of water, waste and sewage treatment, as well as transport. ZPORR was replaced by 16 regional operational programmes, which meant that partial decentralization took place in management over funds of cohesion policy instruments, consisting in creation of programmes separate for each voivodeship in case of which the functions of managing institutions (defining the main priorities for the spending of the funds with particular reference to unique regional circumstances) were committed to voivodeship authorities. In order to support their implementation the funding was provided amounting to 15.6 bn EUR (Table 2), i.e., more than $30 \%$ of overall Community funds designated for financing all operational programmes in Poland .

The current financial perspective 2014-2020 in Poland constitutes continuation of investment logic carried out in the years 2007-2013 including further decentralization of expenditure (in total more than $40 \%$ of funding in the 2014-2020 perspective was allocated to regional programmes, Table 2). Development goals were indicated in the Partnership Agreement and made more coherent with priorities defined in the national medium-term strategy: Strategy for Responsible Development. The key aspect is adjustment of intervention to potentials and priorities of given territories (further territorialisation of developmental policies. 


\section{Key aspects of EU cohesion policy and spatial planning in Poland}

\section{Polycentricity and suburbanisation}

Polycentric development is one of the important pillars of development in Europe. However, differentiated characteristics of settlement network in EU member states determines heterogeneous suburbanisation processes going on in the particular areas. Against this background, Poland's example is particularly worth noting, where expansion of areas designated for building purposes occurred in dispersed and chaotic way. Therefore the issues connected with the subject of polycentricity and suburbanisation are distinctly stated in planning and strategic documents. However, tangible and effective measures regarding suburbanisation and uncontrolled dispersion of built-up development are difficult to observe. The most significant condition - a defective legal system, clearly promoting and guaranteeing the constitutional primacy of individual property rights for development at the expense of the common good, has remained unchanged for years. The - so far undertaken - legislative initiatives have failed. This results in a strong, deepening crisis concerning land management, including the high costs of servicing dispersed, chaotic settlement on the outskirts of cities and tourist areas, traffic congestion, environmental damage, etc.

The impact of cohesion policy on polycentric development and suburbanisation increases along with transition into lower levels of territorial governance. It is closely related with the quality and functioning of the entire planning system in Poland. During transformation, a strong emphasis in the spatial development of Poland was placed on the largest urban centres (as a result of market mechanisms) or on rural areas. This has led to a situation, in which regulations formally concerning supporting polycentricity were robustly exposed (especially in the National Spatial Development Concept 2030, NSDC 2030 2012), but virtually not implemented, particularly at sub-regional level. As a consequence, spatial polarization of the country regarding various aspects (demographic, economic) has deepened. Even more pronounced disparities occurred at regional level - especially in the mazowieckie voivodeship. The basic document - National Development Strategy 2020 (NDS 2012) does not mention polycentricity at all, while another - National Strategy for Regional Development 2010-2020: Regions, cities, rural areas (NSRD 2010) - only casually refers to this concept in two places. Favourable changes occurred as a result of some infrastructure investments (after 2004), but these were selective in spatial terms. The Strategy for Responsible Development (SRD 2017), adopted in 2017, strongly supports medium-sized cities, so far highly underestimated in the settlement network of the country, offering dedicated support projects to these cities.

One may indicate numerous problems in the field of spatial planning with regard to cohesion policy and investments utilizing the available EU funding. Particularly at the local level in the studies on conditions and priorities of spatial planning, investment pressure in terms of excessive designation of lands for development purposes is noticeable, on the one hand due to significant developmental trends, and on the other owing to chances of becoming beneficiary of EU investment support. An implicit relationship between cohesion policy funding and the built-up areas dispersion can be thus observed. The example of such relationship is Warsaw suburban municipality Lesznowola. Due to opportunities offered by EU to acquire funds for technical infrastructure and education, the whole area has been equipped with technical infrastructure. As a result nearly the entire area of the municipality, in line with local spatial plans of spatial development, is designated for development, in spite of the fact that the population absorptive capacity of this plan is several times higher than the current population (Olbrysz \& Koziński 2011; Kowalewski et al. 
2014). Supra-municipal analyses financed by EU funds revealed the necessity of rational investment and economic effectiveness, however, they did not have obligatory status in implementation of conclusions and provisions in local spatial development plans that are binding acts of local law. EU funds do not allow for financing the very stage of preparations of local spatial development plans.

Planning circumstances of investments co-financed by cohesion policy had a negative resonance in the case of investment in the areas not covered by local spatial development plans. To carry through this type of investment, it was necessary to receive decision on land development, which because of lengthy procedure often made it impossible to request funding by EU within a given time period or which exposed a local government to pressure from investor's lobby and made it prone to issuing decisions on land development that are unjustified from the economic rationale point of view or by social welfare or by spatial order objectives.

In response to problematic questions related to rationality of investments financed by EU funds, Regional Territorial Investments (RTI) were identified as promoting good practices in regard to polycentricity. RTI are supposed to act as a tool for urban development, but in a functional sense, i.e. going beyond their administrative borders, within justified area, designated on the basis of relevant documents at supra-local level and studies. These instruments act a good example of integrated spatial planning. Their most desired feature is the promotion of investment location in connection with natural functional areas such as daily urban systems. This is crucial both in terms of polycentrism, improving the efficiency of areas with dispersed settlement as well as inter-communal cooperation. As an example of a successful RTI in mazowieckie voivodeship a bundled investment "Establishment of Integrated Multifunction Passenger Exchange Node in Siedlce. Expansion and modernization of the associated communication system of the city and the subregion of Siedlce" was considered.

Polycentric development as a spatial strategy to combat spatial chaos and uncontrolled suburbanisation is present in national/regional planning documents, defining the regional cores. Nevertheless, balanced territorial development is difficult to achieve in the case of a malfunctioning land development control system. In Polish case study the national- or regional-level documents set out common goals of promoting polycentric and balanced territorial development and preserving compact cities, whereas at the same time the land-use regulation development activities do little to assist the pursuit and achievement of these objectives. Moreover, investors tend to influence the determination of local spatial development plans, and previously or currently released state regulation reduces possibilities for urban sprawl to be prevented. Newly-introduced tools (supra-communal/regional/territorial development planning documents or agencies), notably compiled with the use of cohesion policy support, aimed the harmonising of project development and emphasised the need for rational investment and economic efficiency. In practice, however, they mostly served in preparation for the programming period and development activities of local actors were not coordinated ultimately. Moreover, they could be characterised as a "struggle for development resources", resulting in local improvements instead of balanced, regional development.

In conclusion, the Polish planning system was not able to stop unfavourable excessive and uncontrolled suburbanisation. It was not favoured by the far-reaching planning autonomy of basic local government units (communes and municipalities). Under these circumstances, the availability of EU funds in some cases additionally compounded the problems. Some co-financed investments were created in areas without the legally bounding local spatial development plans (but based on a decision on land development), therefore in result they were contributing to the increase 
of spatial chaos. Relatively easy access to financial resources sometimes caused rescaling of investments. Co-financing of water supply and sewage systems resulted in the reduction of potential costs related to the construction of single-family houses far from densely developed areas. In the context of development dispersion and suburbanisation, EU investments had an adaptive character (e.g. providing utility infrastructure) rather than mitigating. Analysis of the Polish case study proves that it would be advisable to modify the competition criteria, in some operational programs (especially in metropolitan areas), so that the co-financing of the investment depended on the existence of local development plans and on the analysis of the future use of constructed facilities (e.g. sport facilities).

\section{Transport infrastructure and accessibility}

In comparison to other Central and Eastern European countries, Poland has had an extremely prolonged gap in the implementation of significant transport investments. The stagnation started around 1980 and in fact lasted until the accession to the European Union in 2004. Under these conditions, the emergence of the European Union support for new large-scale undertakings (commencing with the pre-accession ISPA program) has resulted in a rapid, though often chaotic, intensification of investment activities. At the beginning of the second post-accession financial perspective (2007-2013), an increased attention was paid to the requirement of clearly defined objectives concerning given investment. In strategic documents formed at state level this was reflected while compiling the up-dated National Spatial Development Concept 2030 (NSDC 2030 2012). In spite of mentioned obstacles, the expansion of a road network has begun to take place (motorways and expressways) characterized by an increasing spatial cohesion. Considerably less spectacular successes have been achieved in terms of rail network development (mainly due to institutional barriers within railway companies). In 2007-2013 along with the current 2014-2020 periods the largest undertakings were implemented within the Operational Program Infrastructure and Environment. At the same time, other transport investments were carried out with the support of regional operational programmes for 16 voivodeships and the Operational Program Development of Eastern Poland. The overall value of transport projects in both financial perspectives (2004-2006 and 2007-2013) exceeded EUR 28 billion, of which vast majority were allocated for the purpose of road investments. The specificity of managing EU funds in the transport sector in Poland was reflected also by a significant share of agglomeration projects (e.g. metro in Warsaw, tram lines), ports (facilities in Gdańsk, Gdynia, Szczecin and Świnoujście) and also, by 2015 , expansion of almost all existing airports in Poland, as well as construction and launching two new ports for regular flights (in Modlin and Lublin). As a result of described investments, there was a significant increase in the level of potential accessibility indicators across the country.

The spatial planning inertia and long procedures resulting from the Spatial Planning and Land Development Act (2003) contributed to the necessity of enacting new regulations to refine implementation of transport investments. Most of new roads, railways and other facilities have been based on these documents. Change in legislation has improved the investment process, but simultaneously "detached" the infrastructure planning from other forms of land management, in particular including development of housing and establishing new large traffic generators (shopping centres).

The impact of cohesion policy upon planning conditions of transport development was considerable. This emerged in the need of applying special acts, environmental regulations, as well as adapting planning documents to European policy objectives (changes in priorities). Generally, the impact of cohesion policy should be evaluated positively, especially at the macro-scale. How- 
ever, according to experts' opinion after the accession to the EU, preservation of pre-determined linear investments has not been assured. This aspect is crucial as progressive settlement dispersion hindered new investment variants. Meanwhile, Natura 2000 sites for instance have often been delimited as conflicting to transport corridors planned for several decades (lack of agreement between ministries responsible for environment and transport). This has often resulted in prolonged conflicts between the General Directorate for National Roads and Motorways - local community - environmental organizations (e.g. eastern bypass road of Warsaw, exit route towards Gdańsk). The most probable outcome of such conflict was a delay in investment, considering that finding alternative routes is either impossible or very costly. The road and railway special acts have accelerated investments, but at the same time they have contributed to diminishing the significance of local plan while determining the final course of new routes. In the Warsaw agglomeration, such pattern results in conflicts, mainly socially based. There has been observed a typical NIMBY ("Not In My Back Yard") effect on a regular basis. Residents' associations question environmental decisions, most often by seeking minor formal errors. The conflict involves active participation of local inhabitants directly affected by expropriation, residents affected by a given investment, the NGO's and often local government authorities. Two-stage judicial and administrative proceedings are in place, thus the possibility of blocking the investment is still high. As the special acts are in force, obstruction occurs at the initial stage when the environmental decision is being issued. Subsequent building permit is already subject to an immediate feasibility clause. Based upon the special acts a given property is under investor's ownership by law. The owner or user receives compensation later.

In the field of environmental protection strong influence upon transport investments has been exerted by the EU regulations, both at the stage of planning and developing environmental impact assessments. As a consequence, cases of changing previously planned routes (aforementioned lack of space for alternative routing) were marginal. However, the investment process has been essentially changed. Regulations of the EU have forced, i.e., construction of fauna passages, acoustic screens and other pro-environmental solutions. In Warsaw, this sometimes led to questionable (often criticized) consequences such as raising soundproof screens by the streets. This was an outcome of changes in national legislation, caused by the European law, but at the same time more stringent standards than in many other EU states have been imposed. Cohesion policy has certainly had a strong influence on the structure and quality of transport investments in urban areas. Undertaken actions were adjusted to recommendations of European transport and urban policies. This resulted in an increased preference for public transport, cycling infrastructure as well as intermodal solutions. A significant constraint for the implementation of transport projects (particularly in public transport) concerned difficulties in cooperation between big cities and other communes of the metropolitan area. Certainly a desired solution enforcing such cooperation has been the Integrated Territorial Investment (ITI) system applied in the current programming period. Moreover, in some voivodeships' authorities have allocated additional funds for the Regional Territorial Investment (RTI) within the Regional Operational Program.

In the current programming period (2014-2020), calls for road investments have been significantly limited. There has emerged a requirement that co-financed roads are now to be linked to TEN-T networks or investment sites. Numerous counties of the particular regions do not meet these necessities. Local planning is adapted to the operational programs in order to obtain the EU funding. Some of the experts interviewed claimed that as a result of such actions, the cohesion policy means allocated to transport were over-scattered. This was fostered by-among other determinants - political primacy of spending the entire budget (authorities are assessed on whether or not they wasted a single euro from EU funds). 
As one of the most significant positive impact of cohesion policy on the process of spatial planning, both development of consultation and mediation procedures has been pointed. Comprehending certain terms along with undertaking actions has become similar to that commonly used in Europe (before this was an issue in the region). A major, direct influence of cohesion policy has also been exerted upon environmental issues (variants in transport investments, environmental impact assessment and social consultation at various phases).

\section{Natural and cultural heritage}

Cohesion policy as a main EU investment policy includes environment and landscape to its programmes and projects, significantly supporting both natural protection heritage as well as cultural heritage. Measures assisted by EU funds, apart from benefits for the indicated fields, may contribute inter alia to activating local entrepreneurship, generating new jobs, e.g., in tourism, to creating proper conditions for economic growth. This results from the fact that similarly as in previous programming periods, also in the current financial perspective (2014-2020) the sustainable development constitutes the key element of that policy. In the area of Poland, similarly as in other parts of Europe, regions linked by particular values of natural and cultural heritage, on the one hand, have a significant endogenous potential, and, on the other, are poorer economically. Cohesion policy by means of numerous programmes and projects, and particularly through financial support and recommended integrated measures addressing the environmental goals, leads to strengthening and protection of biodiversity as well as of landscape. Regions that are characterized by extraordinary values of natural and cultural heritage (including Natura 2000 network and other territorial forms of nature protection) have a chance to properly utilize their local potential, especially for the development of what is termed as "business \& biodiversity", inter alia in tourism and agrotourism and ecological farming. Regional endogenous potential following from valuable environmental and landscape resources, apart from creating developmental chances, generates however numerous limitations, concerning, among others, infrastructure, land development, agriculture. From one point of view, it requires paying greater attention to natural and cultural heritage in development programming, territorial governance, and primarily in spatial planning. However, from another standpoint, referring these questions to cohesion policy, this provides much greater opportunities of projects and funds acquisition.

Of key importance for the Polish regions of high landscape and natural values were programmes such as: 'Operational Programme Infrastructure and Environment', 'Operational Programme Development of Eastern Poland' and 16 regional operational programmes, but support was provided also from other instruments, such as, for example: LIFE Nature, LIFE+. Thanks to significant assistance offered by cohesion policy, a number of plans for protection schemes and other documents connected to nature protection were worked out, mainly linked to Natura 2000, as well as carrying through many programmes and protective measures. Under operational programmes, in addition to measures and actions towards protection and promotion of bio- and geodiversity, a wide range of measures were implemented concerning improvement of environment, including curbing negative climate change and adaptation to climate change. As regards cultural heritage, the main areas of support underwent reorientation. Initially, i.e., by 2013 these areas were oriented towards protection and cultivation of cultural heritage, development of cultural infrastructure and support for services linked to culture, but since 2014 they were refocused on the use of investments in cultural heritage towards development and assistance for creative clusters, creativity and digitalization. 
Concerning agri-environmental schemes operating within the Rural Development Programme, of greatest significance for natural heritage was a package of measures dealing with protection of endangered birds and natural habitats within the Natura 2000 area. To protect a landscape, also of high importance were actions promoting systems of farming designed to protect and shape a traditional landscape and to improve ecological awareness of rural population. A crucial barrier to greater effectiveness in the use of these funds is optionality in implementation of agri-environmental programmes. Environmental packages for this programme are very often introduced on too small areas, or only randomly, being directed towards packages with moderate nature protection requirements. Insufficient coordination regarding protection of the whole ecosystems in number of cases weakens the factual protection of environmental habitats. Exclusion from the programme some of the valuable habitats, which initially were covered by subsidies (e.g. high and transitional bogs, reeds), reduces possibility of their protection. Programmes and measures supported by EU funding still have a dispersed spatially or random character. Therefore it is necessary to change the approach be refocusing the efforts on systemic approach, and also on creation of mechanisms supporting integrated measures.

Funds, apart from measurable effect, also have an impact on new ways of actions coordination and communication between administration levels and/or agencies both on a horizontal as well as vertical planes. It may result from the fact that, as regards management, competencies and obligations, they are characterized by a marked separation between management over natural and cultural heritage. Nature protection and cultural heritage constitute two different areas of sectoral policy and two separate management centres both at the regional and national level. Competencies of representatives of government administration in voivodeships and regional government administration are oftentimes ambiguously defined or in parts coincide with each other, which hampers coordination of actions, management and planning. Similarly, there is often a lack of coherence between documents elaborated at different levels of governance and spatial planning. Strategic documents of general character at the national and regional level are usually characterized by a relative coherence. However, regional and municipal strategies have usually lower coherence, both between spatial levels as well as with sectoral documents.

Despite growth in number of regulations and entities linked to natural and cultural heritage protection, and despite introducing the requirement to prepare strategic environmental assessment (SEA) for all policies, studies and local spatial development plans, in many aspects of the analysed matter the situation has been worsened, which is caused by deficient spatial planning system. There is scarcity of spatial development plans prepared for groups of municipalities within functional areas, which is particularly important with reference to areas with high natural and cultural values (especially around large cities). These plans could be an instrument supporting better coordination between protection of natural-cultural heritage and spatial planning, due to concentration of natural or natural-cultural values and protection of important natural structures, such as, for example, green rings or ecological corridors. However, still too often local spatial development plans are prepared for small fragments of municipalities and have usually investment character. In the case of lack of local spatial development plan, land development under new investment project is carried out on the basis of decisions on land development, which do not have legal requirement of compatibility with the study of conditions and directions of spatial development of a given municipality, but constitute basis for obtaining building permission.

Despite numerous programmes promoting education and ecological awareness as well as and a significant increase in the participation of local communities in the spatial planning process, social participation, apart from advantages, has sometimes certain disadvantages. This follows from the gap between putting individual's benefit much higher than the public good. 
There are cases where regulatory-protective character of local plans is disapproved by local communities. For example, in podlaskie voivodeship, there were situations when local spatial development plans that were well coordinated with protection plans for Natura 2000 were rejected because of the opposition from local population. In the face of serious restrictions concerning development within the area of Natura 2000 and its surroundings, many municipalities resigns from drawing up local spatial development plans, carrying out land development based on administrative decisions.

Among major benefits one may consider: (a) introduction of strategic environmental impact assessments for all categories of spatial development plans as well as setting up other documents that contribute to paying ever greater attention to natural and cultural heritage issues in the process of spatial planning; (b) growing ecological awareness and social participation; (c) adopting the landscape law as a basis for introduction of landscape audit. In spite of attempts to ignore environmental requirements in the planning process (e.g., an attempt to construct bypass road passing through the Rospuda river valley), environmental and sustainable development issues are taken into account to an ever growing extent already at the stage of planning and preparing investment, which results from introduction of requirement to carry out environmental impact assessments (EIA, SEA). Environmental decision forced inter alia the construction of crossings for animals under and over the express road and other ecology-friendly developments. Ecological corridors and green ring roads are becoming an ever popular element of plans. Due to new concept of eco-system services, gradually one can observe a change in approach to valuable nature areas in spatial planning.

The level of coordination of relations between cohesion policy and spatial planning in regard to natural heritage protection is better evaluated than with reference to cultural heritage. Local planning shows a little interest in protection of the cultural landscape as a whole which concerns in particular protection of valuable historical spatial arrangement, both in urban and rural areas, and broader vicinity of monuments. Two main reasons can be indicated. First of all, the opportunities provided by the local plan for the protection of such areas are still too seldom used. Secondly, from the small interest of municipalities in the creation of cultural parks (in 2016 there were 36 cultural parks in Poland, established in 2002-1016). A cultural park is an important instrument for the protection of the cultural landscape with monuments and the surroundings of these objects, as well as historic spatial layouts. In addition, there is a statutory requirement to draw up a local spatial development plan for such an area. Unsatisfactory situation is a result of low social interest in this problem and long-term lack of effective tools. The situation concerning the protection of cultural heritage is characterized in most cases by point effects, because support is provided usually to singular objects or sites, and thus is spatially dispersed. There is no coordinated and systemic approach to spending of funds. However, as regards protection of monuments and documentary-inventory works, support from EU funds significantly improved state of the art and availability of information concerning cultural heritage sites and, above all, improved their condition.

To sum up, it needs to be highlighted that with respect to natural and cultural heritage, in spite of still existing weaknesses, there occurs increasing integration between cohesion policy and spatial planning, though the system of spatial planning generally maintains poor level of preparation in terms of projects' coordination and more effective utilization of funds. In order to increase synergy effects between cohesion policy and cultural-natural heritage protection, the projects and activities must be even better coordinated spatially already at the stage of granting the funds, and oriented towards long-term vision of regional spatial development. It is necessary to develop more effective mechanisms promoting projects which firstly combine two fields: natural heritage with cultural heritage, secondly, protect natural and cultural heritage with the simultaneously development of tourism and other activities based on the endogenous potential. 


\section{Conclusions}

Poland, including the regions analysed, obtained significant funds from the EU cohesion policy in 2004-2016. Their utilisation is generally rated high. The strong relationship between the implementation of cohesion policy objectives and spatial planning and territorial management was observed. This relationship was related to various problematic areas, which corresponded to individual operational programs. It was clearly visible especially in:

- planning conditions (including barriers) for the implementation of EU investments in the national space;

- adaptation activities (including the so-called "special acts") changing the system in terms of the needs resulting from the efficient spending of EU funds;

- dependence of certain investments on the implementation of European law directives.

Furthermore, there was also an indirect influence on the discussed relationship, among others related to general economic development and the enrichment of local societies (partly as a result of Poland's accession to the EU). It is not without significance that in the period directly preceding the EU membership, significant institutional changes, partly related to the planned accession, took place in the Polish planning system. These included the reform of the administrative system (1999) and the new Spatial Planning and Land Development Act of 27 March 2003.

Implementing cohesion policy aiming at polycentric settlement development faced many challenges related to inefficient Polish planning system. The far-reaching planning autonomy of basic local government units joined with the process of issuing building permits based on administrative decisions in case of a lack of the local spatial development plans results in excessive and uncontrolled suburbanisation. Under these circumstances of a malfunctioning planning system, the availability of EU funds in some events additionally compounded the problems. This was a case for some co-financed investments, created without the local spatial development plans and in the end contributing to the spatial chaos; the rescaling of the infrastructure investments due to the pressure to allocate more land for development purposes; and later on the dispersed settlement occurring due to the accessible infrastructure. Analysis of the Polish case study proves that it would be advisable to include in the co-financing criteria the compliance of the prospective investment with the existing planning documents, as well as its operational and economic legitimacy.

The role of the planning system as a barrier to efficient implementation of cohesion policy transport projects was most evident in the urbanized areas, especially in the vicinity of Warsaw and other biggest cities. The suburbanisation process, related to the drawbacks of the planning system has directly affected the difficulty in conducting transport projects. Due to enacting special acts, the investments were successfully completed in line with the EU policies (especially in terms of environmental protection, but also in terms of mobility changes - mobility plans). A very positive aspect was the introduction of the ITI and RTI instruments and coercion of local governments to cooperate, particularly in public transport projects. In case of investments implemented at minor scale, including those located more peripherally, project selection may often raise doubts. Planning transport investments should ultimately be re-integrated with local planning. In case of selected large linear investments (for which implementation of route variants is practically no longer possible) and spatial (such as NIMBY) conflicts indispose their accomplishment (e.g. the eastern bypass road of Warsaw), it is necessary to maintain a dedicated implementation path. In the areas located further away from large metropolises, funds allocated for the modernization of regional roads and railways were sometimes overly dispersed (which was the result of a kind of egalitarianism, 
according to which each part of the province should get some investment...). Thus, access to cohesion policy support for major transport projects in metropolises must be flexible. This applies both to the criteria of profitable units (cities with high nominal GDP per capita may not be able to realize large investments themselves, especially in public transport), as well as rigorous preferences only for specific modes of transport (intermodal solutions are often the only ones that can increase the system's efficiency).

Interactions between spatial planning and territorial governance with the protection of natural and cultural heritage are very complex. Regional government documents are characterized by a relative coherence. They are also consistent with documents at national level. However, there is much less consistency to be observed by regional and communal strategies. In this case, such interactions cannot be clearly assessed. Programmes, supported by EU funds, too frequently have a spatially dispersed and point-type character, there is a necessity to change the approach by directing the actions toward systemic programmes, as well as to elaborate the mechanisms of supporting such actions. This concerns especially the entire ecosystems, ecological corridors and cultural landscapes protection. Common plans of spatial development for groups of communes within given functional areas can be viewed as an instrument supporting the accomplishment of better coordination and cohesion in combining the natural and cultural heritage protection with spatial planning, due to concentration of natural or natural and cultural values.

In summary, it should be emphasized that in the period 2004-2016, cohesion policy played a significant role in Poland in the area of infrastructure development, polycentricity and suburbanisation processes as well as in the natural and cultural heritage protection. The existing planning system did not fully support the achievement of these goals. This applies in particular to spatial planning system, which was reformed directly before the accession to the EU by, among others, cancelling all local spatial development plans established before 1994. As a result, it was necessary to pass special purpose acts. In addition, in some cases access to EU funds indirectly favoured undesirable transformations of space (dispersion of development). Spatial benefits related to cohesion policy were greater on the national scale and in the peripheral areas. At the regional level, especially local (including metropolitan), redistribution of funds was not sufficiently anchored in the planning system.

Moreover, since the beginning of EU integration, there has been, partially induced by cohesion policy (as well as dependent on this policy), the process of learning and improving the territorial management, which is also related to the quality of the management and human capital at the regional and local level of self-government units. Territorial governance is struggling with the punctuality of investments implemented with EU funds, partly due to differences in a coherent vision of spatial and economic development of the region (despite the appropriate documents at the strategic and operational level), as well as the willingness to use available structural funds, despite the lack of significant effects for the region. Nevertheless, it should be emphasized that with each subsequent EU financial perspective, integration of territorial governance and cohesion policy is more efficient. 


\section{References}

Börzel T., Risse T., 2000. When Europe Hits Home. Europeanization and Domestic Change, European Integration Online Papers, vol. 4, no. 15, pp. 1-13.

Cotella G., 2018. Editorial: EU cohesion policy and domestic territorial governance. What chances for cross-fertilization? Europa XXI, vol. 35, pp. 5-20.

Cotella G., Janin Rivolin U., 2011. Europeanization of Spatial Planning through Discourse and Practice in Italy. disP - The Planning Review, vol. 186, pp. 42-53.

Dühr S., Stead S., Zonneveld W., 2007. The Europeanization of spatial planning through territorial cooperation. Planning, Practice \& Research, vol. 22, no. 3, pp. 291-307.

Gorzym-Wilkowski W., 2013. Planowanie przestrzenne województwa. Teoria-ustawodawstwo - praktyka. Lublin: Wydawnictwo UMCS.

GUS, Local Data Bank, https://bdl.stat.gov.pl/bdl/start [2 November 2018].

Hans S., Böhme K., 2018. Planning in Luxembourg: innovation and tradition under one umbrella? Europa XXI, vol. 35, pp. 57-68.

Komornicki T., 2018. Spatial Planning in Poland - The territorial perspective. [in:] J. Farinós i Dasí (ed.) Territorio y estados. Elementos para la coordinación de las políticas De ordenación del territorio en el siglo xxi. Tirant Humanidades: Valentia, pp. 529-562.

Komornicki T., Bednarek-Szczepańska M., Degórska B., Goch K., Szejgiec-Kolenda B., Śleszyński P., Haarich S., Corbineau C., Has C., Varghese J., Joyce D., Smas L., Lidmo J., 2018. COMPASS - Comparative Analysis of Territorial Governance and Spatial Planning Systems in Europe Applied Research 20162018 Final Report - Additional Volume 6 Case Studies Report. ESPON, Luxembourg.

Kowalewski A., Mordasewicz J., Osiatyński J., Regulski J., Stępień J., Śleszyński P., 2014. Ekonomiczne straty i społeczne koszty niekontrolowanej urbanizacji w Polsce - wybrane fragmenty raportu. Samorząd Terytorialny, vol. 4, pp. 5-21.

Kowalewski A., Markowski T., Śleszyński P. (eds), 2018. Studia nad chaosem przestrzennym, Studia KPZK PAN, 182, Warszawa.

Nadin V., Fernández Maldonado A. M., Zonneveld W., Stead D., Dąbrowski M., Piskorek K., Sarkar A., Schmitt P., Smas L., Cotella G., Rivolin U. J., Solly A., Berisha E., Pede E., Seardo B. M., Komornicki T., Goch K., Bednarek-Szczepańska M., Degórska B., Szejgiec-Kolenda B., Śleszyński P., Lüer C., Böhme K., Nedovic-Budic Z., Williams B., Varghese J., Colic N., Knaap G., Csák L., Faragó L., Mezei C., Kovács I. P., Pamer Z., Reimer M., Münter A., 2018. COMPASS - Comparative Analysis of Territorial Governance and Spatial Planning Systems in Europe. Applied Research 2016-2018 Final Report, ESPON, Luxembourg.

Nadin V., Zonneveld W., Stead D., Fernández Maldonado A. M., Dąbrowski M., Piskorek K., Schmitt P., Smas L., Cotella G., Rivolin U. J., Komornicki T., Siłka P., Lüer C., Böhme K., 2018. COMPASS - Comparative Analysis of Territorial Governance and Spatial Planning Systems in Europe Applied Research 2016-2018 Final Report - Additional Volume 2 Methodology. ESPON, Luxembourg.

Narodowe Strategiczne Ramy Odniesienia 2007-2013 wspierajqce wzrost gospodarczy i zatrudnienie. Narodowa Strategia Spójności. 2007. Ministerstwo Rozwoju Regionalnego. Warszawa.

Narodowy Plan Rozwoju 2004-2006, 2003. Przyjęty przez Radę Ministrów 14.01.2013 r., Warszawa.

NDS 2020, 2012. National Development Strategy. Council of Ministers Resolution of September 25, 2012, Polish Monitor of November 22, 2012, no. 157, item 882.

NSDC 2030, 2012. National Spatial Development Concept 2030. Council of Ministers Resolution of December 13, 2011, Polish Monitor of April 27, 2012, no. 239, item 252.

NSRD, 2010. National Strategy of Regional Development 2010-2020: Regions, Cities, Rural. Areas. Council of Ministers Resolution of July 13, 2010, Polish Monitor, no. 36, item 423.

Olbrysz A., Koziński J., 2011. Raport o finansowych skutkach polskiego systemu gospodarowania przestrzeniq, Zawód: Architekt, vol. 5.

Pámer Z., 2018. How governance counts? Comparative analysis of activity and funding patterns of Central European cross-border cooperation programmes. Europa XXI, vol. 35, pp. 111-126. 
Perger É., 2018. Planning and development activities in functional regions - the Hungarian case. Europa XXI, vol. 35, pp. 37-56.

Smas L., Lidmo J., 2018. Organising regions: spatial planning and territorial governance practices in two Swedish regions. Europa XXI, vol. 35, pp. 21-36.

Spatial Planning and Land Development Act of 27 March 2003 (Ustawa o planowaniu i zagospodarowaniu przestrzennym z dnia 27 marca 2003 r.).

SRD, 2017. Strategy for Responsible Development. Council of Ministers Resolution of February 14, 2017, Polish Monitor of March 15, 2017, no. 8, item 260.

Territorial Agenda of the European Union 2020. Towards an Inclusive, Smart and Sustainable Europe of Diverse Regions, 2011. https://ec.europa.eu/regional_policy/sources/policy/what/territorial-cohesion/territorial_agenda_2020.pdf.

Umowa Partnerstwa 2014-2020, 2017. Ministerstwo Infrastruktury i Rozwoju. Warszawa.

Węcławowicz G., 2002. From egalitarian citizen theory to non-egalitarian cities in practice: the changing social and spatial patterns in Polish cities. [in:] P. Marcus, R. van Kempen (eds.) Of states and cities. The partitioning of urban space, Oxford Geographical and Environmental Studies, Oxford University Press: Oxford, pp. 183-199.

Williams B., Varghese J., 2018. Examining the impact of EU cohesion policies aiming to reduce regional and social disparities with examples of policy impacts in Ireland. Europa XXI, vol. 35, pp. 89-110. 